\title{
THE NEIGHBOURHOOD AS A CONTEXT OF RESPONSIBILITY
}

\author{
Wim Ostendorf \\ AME, Department of Geography and Planning, Universiteit van Amsterdam \\ Nieuwe Prinsengracht I30, 1018 VZ Amsterdam, The Netherlands \\ e-mail: W.J.M.Ostendorf@uva.nl
}

\begin{abstract}
The history of the role neighbourhoods are expected to play in everyday life of the residents is highly dynamic. This paper gives an overview. Some hundred years ago neighbourhoods formed the almost complete framework for everyday life. This changed due to increasing mobility. Many people expected the end of the relevance of the neighbourhood, but in a new role the neighbourhood will be quite important: as a context of responsibility for the residents.
\end{abstract}

Key words: neighbourhood, community, daily mobility, urban field, social integration, urban policy.

\section{INTRODUCTION}

The neighbourhood is seen in many different ways. As a matter of fact one can speak of a continuum or a scale with on the one end views that underline the extreme importance of the neighbourhood and on the other end views that state that the neighbourhood in this era is without any relevance. Such a wide variety is a strange thing. That is to say, an empirical science as human geography is supposed to confront contested ideas with reality in order to find out to what extent the various views correspond with empirical data. In this contribution I will present a number of the views on urban neighbourhoods and discuss these views critically. Based on these views and the empirical support of these views I will in the conclusion present the view that is in my opinion the most promising: the neighbourhood as a context of responsibility, in which the residents do take and are allowed to take responsibility for the development of the neighbourhood in their own hands.

\section{THE NEIGHBOURHOOD AS A FUNCTIONAL UNIT}

Until 1850 or 1900 the neighbourhood formed the territorial framework, within which almost all inhabitants used to live their daily lives. Within the neighbourhood one found 
work, housing, social relations and, as far as time allowed, recreation. Examples of such neighbourhoods are described by Frankenberg (1969). This local orientation was an unavoidable consequence of the very limited possibilities for mobility in those days: a lack of free time and a lack of means of transport just made it impossible in every day life to move away from the own neighbourhood. This created the necessity to live very near the place of work. Therefore the dispersal of population and services depended at the level of neighbourhoods completely on the dispersal of jobs (Vance, 1966). Within such neighbourhoods one found employer and employee, doctor and patients, poor and rich, young and old. In other words, these local communities were strongly balanced and characterised by a heterogeneous composition in social respect. They also were rather stable, based on the presence of families and firms with strong local roots. This stability also resulted in a local identity in cultural respect, based on tradition of generations. So, such neighbourhoods used to form well-integrated functional units. Basis for the integration was the local autonomy and the resulting strong mutual dependencies and functional relations between the residents in almost all aspects of life. The presence of different social classes did not form an impediment for this integration. On the contrary, coordination of interaction was self-evident based on the functional mutual dependencies. This does not imply that mutual feelings were always sincere and warm. But the mutual dependency and the fact that meeting each other was unavoidable resulted in 'local rules' preventing open conflicts. (Frankenberg, 1969, p 249 and $\mathrm{p} 255)$.

\section{THE NEIGHBOURHOOD AS A PLACE TO FIND SIMILAR PEOPLE AS NEIGHBOURS}

The situation of neighbourhoods as functional units has changed completely over the last hundred years. The continuously increasing possibilities for moving in time and space shorter working hours, faster and private means of transportation and more money for paying for transportation - opened the possibilities for more and more households to increase the distance between the place of residence and the place of work. In this way they could give more attention to their individual preferences regarding housing. This process resulted in new forms of socio-spatial differentiation. Population categories with specific social characteristics, especially regarding income, the presence of children and cultural identity concentrated in residential environments that fitted their preferences and their (financial) possibilities, resulting in urban social areas, such as 'goldcoasts', middleclass neighbourhoods, workingmen's neighbourhoods. This process started in cities, but in later phases with strong processes of suburbanisation also applied to metropolitan regions, giving rise to suburban areas housing families and urban areas with smaller households, fitting with lifestyles that aim at familism in suburban areas or careerism in urban places (Bell, 1968). In this situation the functional unit is no longer the neighbourhood, but the metropolitan region. The neighbourhood is no longer heterogeneous or balanced, but homogeneous with respect to a certain category of households. Selective migration is adding to this homogeneity. And the increasing variety of households regarding income and num- 
ber of jobs within the household, regarding the presence or absence of children and regarding cultural and ethnic background) add to this differentiation between neighbourhoods. The neighbourhood is also no longer an experience for the complete life of the residents, but a choice for a particular phase in the lifecycle. So, neighbourhoods are less stable and more sensitive for change. Especially urban neighbourhoods with accommodation for rent can change very fast; suburban neighbourhoods with a large proportion of owner-occupiers use to be more stable.

In this situation the neighbourhood is a place where on finds an accommodation and a location that fit to the specific characteristics of the household. One also finds there a similar kind of households, not another type f people, but 'people like us'. This homogeneity is appreciated, because it helps to create smooth social relations and to prevent conflict in a situation that is not based on mutual dependencies. Small social distances make social relations easier and help that one can anticipate successfully on the norms and values of the others. Social integration is not based on a functional unit, but it is now based on homogeneity in social respect, i.e. on similarity in social characteristics (Ostendorf \& Vijgen, 1982).

\section{THE NEIGHBOURHOOD AS A PLACE WITHOUT RELEVANCE IN AN ERA OF COMPLETE MOBILITY}

In the last section I argued that patterns of daily mobility changed from the neighbourhood as an encompassing framework to the metropolitan region as an encompassing framework. Not everybody will agree with this view. Many people - sociologists more than geographers and people impressed by technological innovations, telecommunication and the internet more than others - think that distance has lost all its importance and that the relevance of neighbourhoods has disappeared completely. This view started early. Stein spoke of the eclipse of community (1960) and Webber (1964) was speaking of the urban place and the non place urban realms. The information-revolution and the possibilities of Internet have renewed this idea and made it stronger. Ideas regarding global cities (Sassen, 1991) and the information society (Castells, 2000) have added to this view. Davies (1994) has discussed these ideas, especially with respect to counter-urbanisation and underlined the continuing importance of distance and location. I do agree with this point of view: distance has not lost its importance in daily life. Even stronger, the importance of distance in everyday life did not decrease over the last decades. I will try to show this for The Netherlands.

Also in The Netherlands the idea of distance without relevance and, as a consequence, a bigger and bigger unit for the planning of urban areas is very popular. In many policy documents regarding physical planning in The Netherlands new concepts are introduced, that relate more to an ideal than to reality. These new concepts are easily accepted and used or even appreciated and that does not add to the preciseness of the discussion. Over the last years regarding the situation of the cities in the western part of The Netherlands the following terms with an increasing scale were introduced: city, daily urban region, Randstad, Compact city, network city, urban network, Delta-metropolis, urban field. The consequence 
of this fast inflation of concepts is confusion: what is behind the concept; is it related to networks, that is to say to relations? Urban form (a concentration of cities, density) does not necessarily imply relations. It is remarkable that regarding these concepts no attention is paid to relations. So, I will elaborate this issue of relations a bit further. The central issue in this respect is not that cities do not have relations with each other, because they do, even at the scale of the complete world; neither what could be possible. The actual relations in space form the central issue: what spatial unit appears to exist looking at the daily interactions of residents and visitors of city and surrounding area. Looking at the daily mobility of the Dutch population: what trips do they make, over what distance or travelling time and what is the purpose of the trip? The source is the Onderzoek Verplaatsingsgedrag (OVG, Research on Mobility) of the CBS, as analysed by Bontje (2001).

Table 1: Number of trips and percentage per distance category, The Netherlands 1987, 1992 and 1997

\begin{tabular}{|l|r|r|r|r|r|r|}
\hline $\begin{array}{l}\text { Distance } \\
\text { in } \mathrm{km}\end{array}$ & $\begin{array}{r}1987 \text { no of trips } \\
(\mathrm{x} 1.000 .000)\end{array}$ & $\%$ & $\begin{array}{r}1992 \text { no of trips } \\
(\mathrm{x} \mathrm{1.000.000)}\end{array}$ & $\%$ & $\begin{array}{r}1997 \text { no of trips } \\
(\mathrm{x} \mathrm{1.000.000)})\end{array}$ & $\%$ \\
\hline $0-1$ & 2282,4 & 14,4 & 2282,8 & 13,3 & 3205,3 & 15,5 \\
\hline $1-2,5$ & 3983,4 & 25,1 & 4167,5 & 24,4 & 5374,1 & 25,9 \\
\hline $2,5-5$ & 2633,7 & 16,6 & 2780,2 & 16,3 & 3242,5 & 15,7 \\
\hline $5-10$ & 2532,5 & 15,9 & 2707,9 & 15,8 & 2997,6 & 14,5 \\
\hline $10-20$ & 2135,8 & 13,4 & 2406,6 & 14,1 & 2675,6 & 12,9 \\
\hline $20-30$ & 865,4 & 5,4 & 923,8 & 5,4 & 1086,1 & 5,2 \\
\hline $30-50$ & 678,2 & 4,3 & 841,9 & 4,9 & 898,0 & 4,8 \\
\hline 50 and more & 783,0 & 4,9 & 998,4 & 5,8 & 1144,3 & 5,5 \\
\hline TOTAL & 15894,4 & 100 & 17108,4 & 100 & 20714,4 & 100 \\
\hline
\end{tabular}

Table 1 shows two important things. In the first place, the number of trips in The Netherlands is increasing strongly. Secondly, that the length of the trips is not increasing, but stable. So, between 1987 and 1997 The Netherlands is becoming more mobile, but within a limited spatial framework. There is no reason to speak of an urban field. But it is correct to speak of a dynamic urban life in the network city. This increased dynamics, to be noticed when looking to the increasing numbers of traffic jams and the increasing numbers of passengers in public transport, is not related to the bridging of longer distances in the daily mobility, but to the increasing participation of women in the labour market, of students in higher education and of many people in spending their leisure time outside the home and often the place of residence.

In table 2 the trips are studied within areas that can be described as large metropolitan regions or as network cities. In the case of Amsterdam this refers to the north wing of the Randstad. The information of table 2 confirms the conclusions of table 1 . In The Netherlands almost $90 \%$ of the trips do not cross the border of the metropolitan region and this share of $90 \%$ does not change over the period studied. In any case it is safe to say that this share is not decreasing in a remarkable way, as is suggested by many people discussing Delta metropolis or urban fields or the disappearing importance of distance. Instead it se- 
ems more appropriate to speak of the metropolitan region or the network city and of the limitations of daily mobility based on the ongoing importance of distance and hence of the neighbourhood.

Table 2: Percentage of trips within regional borders, 1987, 1992 and 1997

\begin{tabular}{|c|c|c|c|c|c|c|c|}
\hline Region & 1987 & 1992 & 1997 & Region & 1987 & 1992 & 1997 \\
\hline Amsterdam & 88,4 & 90,0 & 89,2 & Breda & 89,0 & 88,3 & 87,4 \\
\hline Rotterdam & 92,0 & 89,0 & 89,1 & Tilburg & 86,7 & 80,1 & 82,9 \\
\hline The Hague & 86,9 & 85,7 & 85,5 & Den Bosch & 83,6 & 80,1 & 83,7 \\
\hline Utrecht & 84,7 & 83,5 & 81,7 & Eindhoven & 92,4 & 90,1 & 88,8 \\
\hline Rest of Randstad & 85,1 & 79,4 & 81,6 & Maastricht/Heerlen & 94,8 & 94,7 & 92,7 \\
\hline Groningen & 89,8 & 89,4 & 87,3 & Northern N Holland & 83,0 & 82,8 & 81,4 \\
\hline Leeuwarden & 91,4 & 89,0 & 88,1 & \begin{tabular}{|l|} 
North Netherlands \\
\end{tabular} & 87,0 & 86,9 & 86,0 \\
\hline Enschede/Hengelo & 93,8 & 92,5 & 92,3 & East Netherlands & 88,0 & 86,0 & 85,3 \\
\hline Zwolle & 82,6 & 83,6 & 81,0 & North Limburg & 90,4 & 90,1 & 88,2 \\
\hline Arnhem/Nijmegen & 87,7 & 83,1 & 84,7 & Zeeland & 93,1 & 93,5 & 93,4 \\
\hline
\end{tabular}

So, it is fair to conclude that The Netherlands over the last decades do not show the rise of urban fields (see also Friedman \& Miller, 1965). The functioning of network cities or polycentric urban regions is more applicable to The Netherlands. In the case of Amsterdam such a region comes close to the north wing of the Randstad, but with clear limits of some 45 minutes of travelling time or some 20-kilometer of distance from Amsterdam. These limits did not really change over the last 15 years, but remained constant. The change is in the number of trips due to a higher participation in mobility, but not in the length of the trips. These findings also imply that new introduced concepts as Randstad, Delta-metropolis or urban field are beyond reality of everyday life (Cortie et al. 1992).

\section{THE NEIGHBOURHOOD AS A COMMUNITY}

In section 2 it was argued that neighbourhoods used to be functional units functioning as well integrated communities, but that this phenomenon is a thing from the past. Nevertheless, the idea of neighbourhoods as communities appears to be very strong and attractive and is used as a Leitmotiv for all kind of ideas, judgements, approaches and policies. Of course some neighbourhoods are more stable than others. Population turnover in urban neighbourhoods uses to be quite high, while suburban neighbourhoods and neighbourhoods in the countryside use to be more stable. In suburban neighbourhoods is the orientation on and interest in the residential environment also stronger than in urban neighbourhoods: families with young children are used to spend more time in their neighbourhood. These facts add to the character of these neighbourhoods as a community. But, as argued in section 3 , the community-character of such neighbourhoods is based on homogeneity with respect to social characteristics and this helps to create smooth social relations and to prevent conflict in a situation that is not based on mutual dependencies and on a life long experience in the neighbourhood. 
Also urban neighbourhoods with a high population turnover are often approached as communities or with the ambition to increase the community-characteristics of such neighbourhoods (Ostendorf \& Musterd, 1997). In such neighbourhoods live specific population categories, often for a short period of time, spending their daily life for a large part outside the neighbourhood and with a very restricted interest in their neighbourhood. One can think of one- and two-person households, as students, yuppies. The idea to adhere to this romantic idea of neighbourhoods as communities is connected with an ambiguous judgement of households circulating within metropolitan regions in order to find a suitable accommodation and location, that fits the private situation of the moment. On the one hand, this judgement is positive, because the processes of emancipation behind this are judged positively: a free choice resulting in an optimal adaptation to personal circumstances. On the other hand, this judgement of emancipation and individualisation is negative, because it increases the problem of social cohesion, resulting in social isolation and alienation. In essence the attempt is to compensate the decreasing importance of family, church, work and associations by 'creating communities', i.e. going back to the role that neighbourhoods used to have in earlier times. The next section discusses the urban policies in The Netherlands aiming at creating communities.

\section{THE NEIGHBOURHOOD AS A TOOL FOR SOCIAL INTEGRATION}

Since WWII the neighbourhood has been in the focus of many policies in The Netherlands. However, the approach of area-based measures with respect to social exclusion has not been constant over time. More clearly: in the period after WWII a large number of approaches have been adopted. This situation has as a positive side that the different approaches can be compared, suggesting answers on questions as the perspective on social exclusion, the indicators used and the changes over time. On the other hand evaluation of policies in The Netherlands is not well developed, causing a rather silent change from one approach to the other. Also the real aims of the policies are seldom explicitly formulated, causing a free space for interpretations by outside observers. However, these interpretations are then free to be criticised again.

In the following scheme I try to present an overview of the different policy-episodes paying attention to some of the above mentioned questions (Ostendorf, 1992).

Before WWII the reinforcement of the CBD was the main idea of spatial policies with respect to cities. Older neighbourhoods were destroyed in order to make room for firms, banks, shops and municipal government-institutions. Housing policies were subordinate to this aim of accommodating the urban economy.

After the WWII in the era of reconstruction this policy continued for a while. But the issue of decent housing grew in importance, for instance with respect to the creation of housing accommodation outside the city, in new towns. In this climate of responding to the housing needs of the population in a period of fast rising incomes, the policy of creating more room for the $\mathrm{CBD}$ at the expense of residential areas soon became politically unac- 
ceptable. The policy changed to 'urban renewal' ('stadsvernieuwing'), a name that had to be understood very carefully in the context of that time. In an era of massive migration of firms from the (inner)city to the suburban zones, urban renewal did not concentrate at all on economic aims, such as the preservation of jobs in the city, but focused completely on housing for the urban poor: in poor neighbourhoods with bad housing conditions urban renewal concentrated on the building of new houses and, in a later stage, on the impro-vement of existing houses, not for new residents, but for the poor residents already living in that area.

Table 3: Urban policies in the Netherlands after WWII

\begin{tabular}{|l|l|l|l|l|}
\hline Name of policy & Main goal & Period & Orientation & Slogan \\
\hline Creating CBDs & Stronger Urban Economy & -1970 & Efficiency & New jobs \\
\hline Urban renewal & Improving urban housing & '70-'80 & Social justice & New houses for n'hood \\
\hline City renewal & Stronger urban economy & '80-'90 & Efficiency & Stop urban degradation \\
\hline Multiple-problem & Help disadvantaged nbhs & '85-'90 & Social justice & $\begin{array}{l}\text { Stop cumulating } \\
\text { problems }\end{array}$ \\
\hline Social renewal & More social cohesion & '90-'94 & Social justice & Higher participation \\
\hline Big City Policy I & Mixed neighbourhoods & '94-'98 & Social justice & $\begin{array}{l}\text { Inmigration of high } \\
\text { incomes }\end{array}$ \\
\hline Big City Policy II & Stable neighbourhoods & '98-'02 & Social justice & Prevent outmigration \\
\hline
\end{tabular}

This changed in the eighties, when it was realised that the urban economy had lost much of its strength due to sub-urbanisation and due to the focus on poor residents and on their housing provision as a leading principle. The name was almost the same, city renewal ('stedelijke vernieuwing'), but the goals were very different: not housing needs, but the reinforcement of the urban economy was most important and the development of the compact city had to create a promising arena for the international economic competition, where city-marketing would persuade multinationals to engage in public-private partnerships bringing new economic growth to the city.

At the end of the eighties it was realised that pure economic goals were harming the necessary social cohesive forces in society. The policy concentrating on areas with multiple problems (Problem cumulating areas) and in a later stage the policy of social renewal had to repair this. The government realised that in an era of loosening ties (family, neighbourhood, church, work, associations) a new social cohesive force was needed, but that the government self would be unable to provide such a tool. Society self had to take this responsibility, civic society had to be activated, firms in particular. The role of the policy was to increase participation in society, via the labour market, but also via all kinds of social relations. Also the neighbourhood was considered as an important vehicle in this respect, because all kind of social relations can be found and/or activated there.

In the nineties the Big City Policy I concentrated on so called 'income-neighbourhoods', a euphemism for areas that are homogeneous with respect to income. That is to say, the policy concentrates on urban neighbourhoods where a relatively large share of the population has a low income. The policy aimed at fighting this sort of segregation, because especially the rise of 'income ghettos' is feared. Therefore, the policy concentrated at restruc- 
turing the urban housing market at the level of neighbourhoods: cheap accommodation had to be destroyed and replaced and mixed with more expensive houses in order to attract more well-to-do households to the neighbourhood. In Big City Policy II the idea of mixed neighbourhoods on the basis of a mixed housing stock remained, but the aim changed somewhat from attracting new well-to-do households to the neighbourhood to offering better chances for the existing residents of the neighbourhood to find accommodation for a housing-career within the same neighbourhood, i.e. preventing the need to go to another neighbourhood for finding other and better accommodation.

Summarising one can say that many policies in The Netherlands regard the neighbourhood as a useful tool for social integration of the inhabitants, i.e. a useful tool for creating community. In this respect it is not realised that most inhabitants feel only in a limited way connected to their neighbourhood and that most inhabitants are not interested to engage in social relations with other people in their neighbourhood when these people are quite different from themselves, i.e. the social distance being too large.

\section{THE NEIGHBOURHOOD AS AN OBJECT OF DESIRE}

The sections above might have suggested that residents do not care any longer about the neighbourhood they live in. It is important to underline that such a view is not correct. Households do care very much about their neighbourhood and try to find, to create or to protect the neighbourhood that they desire (Musterd \& Ostendorf, 1998). There is all kind of evidence to support this view about the importance of the neighbourhood. In the first place survey-research that asks the residents about their opinion on the neighbourhood. Such research always finds that people do care about their neighbourhood and about their neighbours. Some population categories, such as young families more than others, like students. As said above, the residents then appear to ask for neighbours being similar to themselves. Secondly there is evidence from migration-research. This finds the same thing: people underline the importance of the neighbourhood (location, location, location) and the ambition to find a neighbourhood that fits to the needs and possibilities of the household; in many cases one is looking for a homogeneous neighbourhood. In the third place there are phenomena as 'white flight' or 'gated communities'; they point to the same thing: trying to find 'neighbours like us' and keep out the others. In this respect gated communities form a special case of a more general tendency to interfere with one's own neighbourhood by organising the residents in residents' organisations in order to promote the creation of a better neighbourhood or to protect the existing one.

So, it is clear that people do care very much about the neighbourhood they live in. But this relation is not for one's complete life, it can be changed: if one can find a better place people do consider moving. And in many cases they do. In other words, the situation is different from the neighbourhood as a functional unit that lasts for the complete life if its residents. But on the other hand it is also clear that people are attached to their neighbourhood. This dual attitude forms the reason to speak of the neighbourhood of limited liability. 


\section{CONCLUSION: THE NEIGHBOURHOOD AS A CONTEXT OF RESPONSIBILITY}

Engelsdorp Gastelaars (1995) uses the concept "woondomein", the residential environment that the residents try to influence or to control. In the process of globalisation someone's dwelling forms an anchor in daily life, in which one spends a lot of time. Next to this the dwelling is a property that needs protection and in connection with the residential environment it gives expression to the identity of the residents. For these reasons one tries to control the residential environment, for instance by influencing the physical characteristics and the social composition. This ambition is not new, but in The Netherlands over the last years it is becoming more manifest because of increased importance of the free (housing) market and increased wealth. The elite shows this ambition already for ages by living on a large and well-protected estate with a large garden and fences or by living on the gold coast. However, in Dutch policies this ambition of exerting influence on the residential environment is not appreciated nor accepted. Dutch government does not know how to handle this ambition. Even stronger, when residents do exert such influence, local authorities appears to be surprised completely. For instance, when residents buy jointly a building in order to prevent that an undesired category of people - such as asylum seekers, users of hard drugs etc. - might be accommodated there (Musterd \& Ostendorf, 1999). The fact that local authorities react completely surprised indicates that one does not understand the ambition of exerting influence on the residential environment. Increasing importance of the free housing market will enhance this. Of course the local authorities have to take care of the general interests that go beyond all kind of NIMBY-actions (Not In My Backyard). But just execrating does not form an adequate reaction with respect to this ambition. It asks for a better balance between general interests and the demand for more influence of residents. It is better to decide for recognition of this ambition and for an organisation of the neighbourhood as a context of responsibility. This can be more effective than the bureaucratic organisation, because this often results in free riders and in tolerance by the bureaucracy. Room for the control of the residential environment also can help to create and protect the identity of different neighbourhoods and as such help to foster the individual responsibility. Increasing the feelings of identity can help to create diversity and individuality in a housing stock that is very homogeneous and uniform.

In short, neighbourhoods are still important, but neighbourhoods can only fulfil a fruitful role if the residents get the room to organise themselves in order to exert influence on their residential environment by channelling their feelings of responsibility for the context they are living in.

\section{Bibliography}

Bell, W., 1968: The city, the suburb, and a theory of social choice. In: S. Greer et al. (eds.): The New Urbanisation. New York, 132-168. 
Bontje, M., 2001: The Challenge of Planned Urbanisation. Urbanisation and national urbanization policy in the Netherlands in a Northwest-European perspective. Thesis AME Universiteit van Amsterdam. Amsterdam.

Castells, M., 2000: European cities, the informational society, and the global economy. In: Deben, L., W. Heinemeijer \& D. van der Vaart (eds), Understanding Amsterdam. Essays on economic vitality, city life and urban form. Amsterdam: Het Spinhuis, 1-18.

Cortie, C., M. Dijst \& W. Ostendorf, 1992: The Randstad a metropolis? In: Tijdschrift voor economische en sociale geografie, vol 83 no. 4, 278-288.

Davies, W., 1994: Counter-urbanization in perspective: images and reality in settlement system change. In: Braun, $\mathrm{G}$ et al eds. Managing and marketing of urban development and urban life. Berlin: Dietrich Reimer Verlag, 221-239.

Engelsdorp Gastelaars, R. van, 1995: Territoriale binding en bestuurlijke organisatie op laag schaalniveau. Advies aan het Ministerie van Binnenlandse Zaken. AME, Universiteit van Amsterdam, $18 \mathrm{pp}$.

Frankenberg, R., 1969: Communities in Britain: social life in town and country. Harmondsworth: Penguin Book.

Friedmann, J. \& J. Miller, 1965: The Urban Field. Journal of the American Institute of Planners, pp. 312-319.

Musterd, Sako \& Wim Ostendorf, 1998: Toekomstige woonmilieus in suburb en stad. Een essay in opdracht van NBM-Amstelland Projectontwikkeling en Vastgoed BV. Publikatie AME, Universiteit van Amsterdam, 31pp.

Musterd, Sako \& Wim Ostendorf, 1999: Beschermen van zijn huis zit de mens in het bloed. In: Trouw, 9-1-1999, p 25.

Ostendorf, W.,1992: Ruimtelijk beleid en de spanning tussen economische en sociale doelstellingen. In: Wiardi Beckman Stichting; Wonen en werken in een vol land. Regionaal ruimtelijk beleid in Nederland, Wiardi Beckman Stichting, Amsterdam, 1992, 49-67.

Ostendorf, W. \& S. Musterd, 1997: Maatschappelijke bezorgdheid over sociale segregatie. In: Raad voor Maatschappelijke ontwikkeling, Kwaliteit in de buurt. RMO-advies No 4. Den Haag: Sdu Uitgevers, 73-100.

Ostendorf, W. \& J. Vijgen, 1982: Segregatie en sociale integratie. De spreiding van bevolking binnen dynamische stadsgewesten. In: Geografisch Tijdschrift XVI, no 4, 368-379.

Sassen, S., 1991:The Global City: New York, London, Tokyo. Princeton, NJ: Princeton University Press.

Stein, M.R., 1960: The eclipse of community. An interpretation of American studies. New York: Harper \& Row.

Vance, J.E. jr., 1966: Housing the worker: the employment structure as a force in urban structure. Economic Geography, 294-325.

Webber, M.M., 1964: Urban Place and the Non Place Urban Realms. In: R. Dykman, M.M. Webber et al. (eds.) Explorations in Urban Structure. Philadelphia: University of Pennsylvania Press, 79-153. 